\title{
COMMUNICATION
}

Cite this: DOI: $10.1039 /$ xoxxooooox

Received ooth January 2012, Accepted ooth January 2012

DOI: $10.1039 / \times 0 x \times 00000 x$

www.rsc.org/

\section{Dihaloborenium cations stabilized by a four-membered N-heterocyclic carbene: Electron deficiency compensation by asymmetric structural changes}

\author{
Madelyn Qin Yi Tay, Balasubramanian Murugesapandian, Yunpeng Lu, Rakesh \\ Ganguly, Kinjo Rei and Dragoslav Vidović*
}

The synthesis, characterization and $x$-ray analysis of dichloro- and dibromo-borenium cations stabilized by a 4membered carbene are reported. The ligand's structural changes, atypical for similar systems, were caused by coordination to electron deficient fragments and its $\mathrm{CN}_{2} \mathrm{P}$ ring strain.

\section{Introduction}

The synthesis and reactivity of group 13 monocations, especially three coordinate borenium cations, have recently gained considerable interest. ${ }^{1-11}$ These boron species were predominantly stabilized by $\mathrm{N}$-heterocyclic carbenes (NHC, A, Figure 1), ${ }^{2 \mathrm{a}-\mathrm{g}, 4 \mathrm{a}, 7}$ tertiary amines $(\mathbf{B})^{21,3 \mathrm{a}-\mathrm{d}, 4 \mathrm{~b}, 6 \mathrm{~b}}$ and various pyridines $(\mathbf{C}){ }^{2 \mathrm{~g}-\mathrm{h}, 3 \mathrm{f}, 5,6 \mathrm{~b}}$ and have been used for borylation, ${ }^{3}$ hydroboration, ${ }^{4}$ haloborylation, ${ }^{5}$ hydrosilylation, ${ }^{6}$ hydrogenation ${ }^{7}$ and Diels Alder transformations ${ }^{8}$ of a diverse range of substrates. With respect to NHC-stabilized borenium cations, five-membered NHCs (A, $n=1$, Figure 1) have been mostly used while an example of a six-membered NHCstabilized $(\mathbf{A}, \mathrm{n}=2)$ borenium cation was also reported. ${ }^{2 \mathrm{i}}$ In this work we wish to communicate the synthesis and characterization of a couple of dihaloborenium cations stabilized by a 4-membered carbene ligand containing a phosphine moiety in its backbone (D, Figure 1). ${ }^{12}$
Figure 1. Most common neutral donor ligands (A, B and C) used for stabilization of borenium cations, and the 4-membered carbene (D) explored in this work.

\section{Results and discussion}

Even though free carbene D (Figure 1) has been isolated and fully characterized we found it extremely difficult to handle. ${ }^{12 a}$ Thus, the carbene was prepared and used in situ by deprotonation of iminium salt 1 in toluene (Scheme 1). ${ }^{12 \mathrm{~b}}$ After addition of hexane and filtration, either $\mathrm{BCl}_{3}$ or $\mathrm{BBr}_{3}$ were added resulting in the immediate formation of a white precipitate. The $\delta_{\mathrm{B}}$ values for these two individual products were typical for other systems containing neutral NHC-borane adducts $\left(\delta_{\mathrm{B}}-0.2\right.$ and $-17.5 \mathrm{ppm}$ for $\mathbf{2 a}$ and $\mathbf{2 b}$, respectively, Scheme 1) and other 4-coordinate boron species eliminating the possibility of spontaneous halide extrusion observed for a borenium cation stabilized by an ortho-substituted pyridine. ${ }^{2 \mathrm{~d}-}$ g,13 The $\delta_{\mathrm{P}}$ values for $\mathbf{2 a}(126.5 \mathrm{ppm})$ and $\mathbf{2 b}(128.3 \mathrm{ppm})$ were upfield shifted with the respect to the same signal observed for $\mathbf{1}$ (135.0 ppm) but in a good agreement with a ruthenium complex containing the same ligand. ${ }^{12}$




Table 1. Selected experimental and theoretical structural parameters for the free ligand, $\mathbf{2 a}, \mathbf{3 a}$ and $\mathbf{3 b}$.

\begin{tabular}{|c|c|c|c|c|c|c|c|c|c|}
\hline & \multicolumn{5}{|c|}{ Bond Distances $(\AA)$} & \multicolumn{4}{|c|}{ Angles $\left(^{\circ}\right)$} \\
\hline & $\mathrm{B} 1-\mathrm{C} 1$ & $\mathrm{C}-\mathrm{N}_{\text {(average) }}$ & B1-X (average) & $\mathrm{P} 1-\mathrm{N} 1$ & P1-N2 & $\mathrm{NCN}$ & $\begin{array}{c}\text { Sum at } \\
\text { N1 }\end{array}$ & $\begin{array}{c}\text { Sum at } \\
\text { N2 }\end{array}$ & $\begin{array}{c}\text { Sum of } \\
\text { endocyclic } \mathrm{CN}_{2} \mathrm{P}\end{array}$ \\
\hline $2 \mathbf{a}$ & $1.633(6)$ & $1.359(6)$ & $1.874(5)$ & $1.794(3)$ & $1.813(3)$ & $101.7(3)$ & $351.6(3)$ & $351.6(3)$ & $357.5(4)$ \\
\hline $2 \mathbf{a}^{*}$ & 1.645 & 1.363 & 1.868 & 1.807 & 1.840 & 101.6 & 355.3 & 352.4 & 357.4 \\
\hline $\mathbf{3 a}$ & $1.586(3)$ & $1.342(3)$ & $1.715(2)$ & $1.787(2)$ & $1.852(2)$ & $103.6(2)$ & $360.0(2)$ & $344.8(2)$ & $357.6(3)$ \\
\hline 3a* & 1.594 & 1.346 & 1.739 & 1.826 & 1.903 & 104.8 & 348.3 & 359.2 & 357.2 \\
\hline $3 \mathbf{b}^{\#}$ & $1.57(1)$ & $1.343(8)$ & $1.875(8)$ & $1.785(6)$ & $1.862(6)$ & $103.5(6)$ & $360.0(6)$ & $345.3(6)$ & $357.2(8)$ \\
\hline Ligand $^{12 a}$ & N/A & $1.380(3)$ & N/A & $1.772(2)$ & $1.773(2)$ & $96.7(2)$ & $355.1(3)$ & $348.2(3)$ & $356.4(4)$ \\
\hline Ligand* & N/A & 1.382 & N/A & 1.803 & 1.807 & 97.3 & 357.8 & 353.3 & 357.5 \\
\hline
\end{tabular}

*Theoretical values for the optimized structures performed with the Gaussian 09 package using B3LYP method with 6-31(d,p) basis set. "The solid state data might not be as reliable as in the other cases due to poor crystal quality.

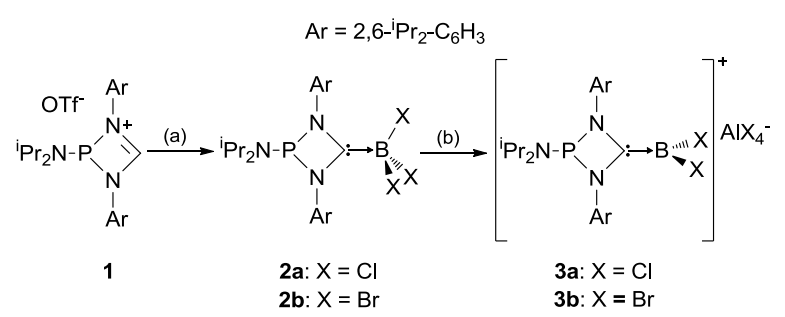

Scheme 1. General synthetic procedure. Reaction conditions: (a) 1.1 equiv of $\mathrm{K}\left[\mathrm{N}\left(\mathrm{SiMe}_{3}\right)_{2}\right]$ in toluene, hexane, 0.57 equiv $\mathrm{BX}_{3}$. (b) 1.0 equiv of $\mathrm{AlX}_{3}$ with respect to $\mathbf{2 a} / \mathbf{2 b}, \mathrm{DCM}$.

Furthermore, compound 2a was crystallographically characterized (Figure 1) and the values for the B1-C1 (1.633(6) A) and the average B-Cl $(1.847(7) \AA)$ bond distances are typical for analogous compounds. ${ }^{2 \mathrm{~d}}$ The NCN bond angle $\left(101.7(3)^{\circ}\right)$ is slightly larger than the corresponding angle observed for the already mentioned ruthenium complex incorporating this carbene ligand. ${ }^{12 \mathrm{~b}}$ Also, the non-planarity of the cyclic $\mathrm{CN}_{2} \mathrm{P}$ fragment was manifested by the values for the sum of the angles around the endocyclic nitrogen atoms of $\sim 352^{\circ}$ (Table 1 and Figure 1), which is consistent with the analogous values observed for other compounds containing this particular fragment. ${ }^{12}$

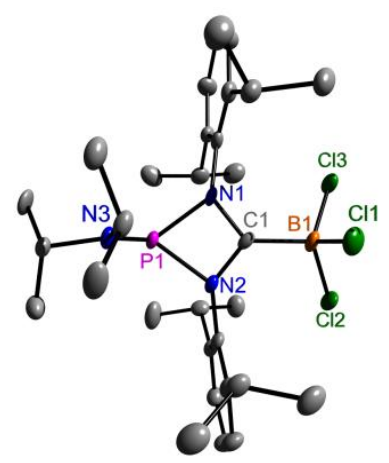

Figure 1. Molecular structure of 2a. Thermal ellipsoids have been drawn at the $30 \%$ probability. All hydrogen atoms and disordered solvent molecules have been omitted for clarity.
As expected, introducing 1.0 equiv of $\mathrm{AlCl}_{3} / \mathrm{AlBr}_{3}$ to a $\mathrm{DCM}$ solution containing $\mathbf{2 a} / \mathbf{2} \mathbf{b}$ resulted in the formation of the target borenium cations $\mathbf{3 a} / \mathbf{3 b}$ (Scheme 1 ) as evident by the $\delta_{\mathrm{B}}$ values of 48.4 and $48.0 \mathrm{ppm}$, respectively, which are in excellent agreement with analogous borenium cations. ${ }^{2 \mathrm{~d}, \mathrm{~g}}$ Formation of the corresponding counter ions ( $\delta_{\mathrm{Al}}$ of 106.3 and $84.0 \mathrm{ppm}$ for $\mathrm{AlCl}_{4}^{-}$and $\mathrm{AlBr}_{4}^{-}$, respectively) was also detected by ${ }^{27} \mathrm{Al}$ NMR spectroscopy. Additionally, ${ }^{31} \mathrm{P}$ NMR spectroscopy provided more evidence for depleted electron density at the newly formed cationic compounds as the $\delta_{\mathrm{P}}$ values for $\mathbf{3 a}(135.5 \mathrm{ppm})$ and $\mathbf{3 b}(136.1 \mathrm{ppm})$ were downfield shifted with the respect to the precursors $\left(\mathbf{2 a}\right.$ : $\delta_{\mathrm{P}} 126.5 \mathrm{ppm} ; \mathbf{2} \mathbf{b}: \delta_{\mathrm{P}}$ $128.3 \mathrm{ppm})$. Both cations have also been elucidated by single crystal $\mathrm{X}$-ray diffraction. Expected $\mathrm{B} 1-\mathrm{C} 1$ and the average $\mathrm{B}-\mathrm{X}(\mathrm{X}=\mathrm{Cl}, \mathrm{Br})$ bond distance shortenings were observed with regard to $\mathbf{2 a}$ and other known precursors. $^{2 \mathrm{~d}, \mathrm{~g}}$ The NCN bond angles for $\mathbf{3 a}$ and $\mathbf{3 b}$ are slightly larger than the same angle observed for $\mathbf{2 a}$. The angles defined by the $\mathrm{BX}_{2}$ and $\mathrm{CN} 2$ planes are virtually identical for both cations $\left(47.6^{\circ}\right.$ and $47.3^{\circ}$ for $\mathbf{3 a}$ and $\mathbf{3 b}$, respectively) suggesting that this particular angle is governed by the steric encumbrance of the carbene substituents. Furthermore, the solid state structures showed no evidence for cation-anion interactions as the shortest $\mathrm{B}^{\cdots} \mathrm{X}_{(\text {anion) }}$ (3a: $5.18 \AA$; 3b: $5.21 \AA$ ) distance for both ionic species was well outside the sum of the van der Waals radii for $\mathrm{B}$ and $\mathrm{X}\left(\mathrm{vdW}_{(\mathrm{B}-\mathrm{Cl})}=\right.$ $\left.3.73 \AA ; \mathrm{vdW}_{(\mathrm{B}-\mathrm{Br})}=3.77 \AA\right)^{14}$
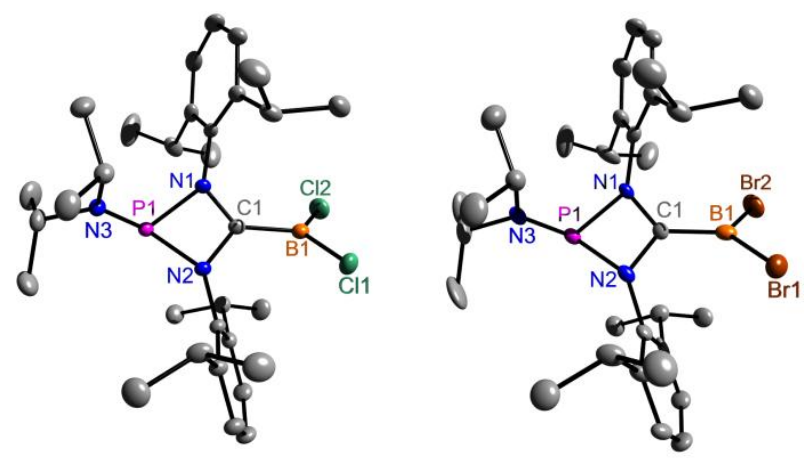

Figure 2. Molecular structures of $\mathbf{3 a}$ (left) and $\mathbf{3 b}$ (right). Thermal ellipsoids have been drawn at the $30 \%$ probability. All hydrogen atoms and the counter ion for both structures have been omitted for clarity. 
However, the most intriguing observation about the solid state analysis for both cations was planarity of one of the endocyclic $\mathrm{N}$ atoms and noticeably different values for the P-N bond distances. The sum of the angles around $\mathrm{N} 1$ for both borenium cations is exactly $360^{\circ}$ while for the other endocyclic $\mathrm{N}$ atom (N2 for both compounds) the sum is around $345^{\circ}$ (Table 1 ). In fact, according to $\mathrm{X}$-ray analyses all systems containing this ligand, including the free ligand, exhibited different degrees of pyramidalization at the endocyclic $\mathrm{N}$ atoms but none of them, apart from $\mathbf{3 a}$ and $\mathbf{3 b}$, had one of the $\mathrm{N}$ atoms strictly planar. ${ }^{12}$ It is noteworthy that solid state analysis of the ruthenium complex containing this ligand revealed that one of the $\mathrm{N}$ atom is almost planar suggesting similar electronic properties between the ruthenium fragment and $\mathrm{BX}_{2}{ }^{+}$moieties (see

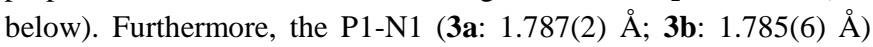
bond distance is considerably shorter than the P1-N2 (3a: 1.852(2) $\AA$; 3b: 1.862(6) ̊) while in the other systems two P-N bond distances are virtually identical. ${ }^{12}$ Initially, we postulated that these observations were a result of the $\pi$ electron delocalization along the CNP fragment for 3a and $\mathbf{3 b}$ rather than the NCN fragment observed for other similar systems. ${ }^{2 \mathrm{a}-\mathrm{g}, 4 \mathrm{a}, 7,12}$ However, after careful examination of solid state data for all compounds containing this particular ligand we concluded that the unequal N-pyramidalization and the discrepancy of the endocyclic P-N bond distances were primarily due to the coordination of a more electron deficient species $\left(\mathrm{BCl}_{3}\right.$ vs $\left.\mathrm{BCl}_{2}^{+}\right)$to the carbene ligand and the inherent $\mathrm{CN}_{2} \mathrm{P}$ ring strain.

First of all, it was suggested that strict planarization at both $\mathrm{N}$ atoms might not be possible due to the $\mathrm{CN}_{2} \mathrm{P}$ ring strain. ${ }^{12 \mathrm{a}}$ Secondly, an increase in the bond angle at the central carbon, known as the carbene angle ( $\angle \mathrm{NCN}$ in this case), for 6 valence electron carbenes decreases the HOMO-LUMO gap and, consequently, increases the $\sigma$-donating properties of the ligand. ${ }^{15}$ Solid state data analysis revealed that the value for the carbene angle systematically increased from $96.7(2)^{\circ}$ for the free carbene to $101.7(3)^{\circ}$ for $\mathbf{2 a}$ and even further to $103.6(2)^{\circ}$ for $\mathbf{3 a}$ presumably to compensate for a more Lewis acidic moiety being coordinated to the ligand (Table 1). It could then be postulated that one of the $\mathrm{N}$ atoms planarized in order to increase its electron donation to the central $\mathrm{C}$ atom and minimize the effect(s) of the increased electron depletion. Planarization of the second $\mathrm{N}$ atom would have resulted in a completely flat $\mathrm{CN}_{2} \mathrm{P}$ fragment which, as suggested, might not be possible due to the ring strain. In fact, it seems that the $\mathrm{CN}_{2} \mathrm{P}$ fragment tends to keep a constant degree of the ring strain as the sum of the endocyclic angles $\left(\sim 357^{\circ}\right.$, Table 1$)$ remain virtually constant regardless of the ligand's structural changes caused by its coordination chemistry. ${ }^{12}$

Density Functional Theory (DFT; using the Gaussian 09 package, B3LYP method and 6-31(d,p) basis set) studies involving the free ligand, 2a and 3a replicated their structural features including the systematic increase in the carbene angle (Table 1) suggesting a decrease in the HOMO-LUMO gap of the ligand moiety. ${ }^{16}$ This was confirmed by the energy-only calculations performed by using the ligand's coordinates from the solid state analyses of the free ligand, 2a and 3a. These calculations illustrated a methodical (i) increase in the energy of the HOMO (- 5.076, - 4.411 and - $4.336 \mathrm{eV}$ for ligand's coordinates taken from the free ligand, $\mathbf{2 a}$ and $\mathbf{3 a}$, respectively), (ii) decrease in the energy of the LUMO (0.017, 0.007 and $-0.012 \mathrm{eV}$ ) and, hence, (iii) decrease in the HOMOLUMO gap (5.093, 4.404 and $4.324 \mathrm{eV}$ ) of the ligand moiety creating not only a better $\sigma$-donor but also a better $\pi$-acceptor. In fact, decreasing the energy of the unoccupied orbitals seemed to play the key role in increasing the average value for the P-N bond distance. According to the natural bonding orbital (NBO) analysis the average electron population of the P-N antibonding orbitals increased with the coordination of electron deficient species (Table 2) resulting in longer $\mathrm{P}-\mathrm{N}_{\mathrm{ave}}$ bond distances (Table 1). Moreover, unequal electron population of the two P-N antibonding orbitals, resulting in noticeably different values for the $\mathrm{P}-\mathrm{N}$ bond distances observed for the borocations, were thought to be also attributed to the $\mathrm{CN}_{2} \mathrm{P}$ ring strain as in the case of the endocyclic $\mathrm{N}$ atom flattening. Therefore, coordination of the carbene ligand to electron deficient species forced the ligand to become more nucleophilic by undergoing certain structural changes. These changes were not uniform with respect to the geometry around the endocyclic $\mathrm{N}$ atoms and the values for the P-N bond distances presumably due to the restriction in the $\mathrm{CN}_{2} \mathrm{P}$ ring strain.

Table 2. Electron population of the P-N antibonding orbitals as observed by the NBO analysis.

\begin{tabular}{lcc}
\hline & P1-N1 & P1-N2 \\
\hline Ligand & 0.13959 & 0.14741 \\
2a & 0.11115 & 0.19573 \\
3a & 0.15595 & 0.28012 \\
\hline
\end{tabular}

In summary, we have successfully prepared dichloro- and dibromoborenium cations stabilized by a four-membered NHC containing a $\mathrm{P}$ atom in its endocyclic backbone. Single crystal X-ray diffraction analysis and theoretical studies suggested that the observed nonuniform $\mathrm{CN}_{2} \mathrm{P}$ ring-based structural changes of the carbene moiety for the borocations were a result of the coordination of electron deficient moieties $\mathrm{BX}_{2}^{+}(\mathrm{X}=\mathrm{Cl}, \mathrm{Br})$ and the $\mathrm{CN}_{2} \mathrm{P}$ ring strain.

\section{Acknowledgment}

We would like to thank A*STAR (grant number: 122-PSF0015) for financial support.

\section{Notes and references}

SPMS-CBC, Nanyang Technological University, 21 Nanyang Link, Singapore 637371, Fax: (+65) 6791 1961, E-mail: dvidovic@ntu.edu.sg $\dagger$ CCDC reference numbers 986260-986262.

Electronic Supplementary Information (ESI) available: Full experimental details, summary of crystallographic date including cif and DFT. See DOI: $10.1039 / \mathrm{c} 000000 \mathrm{x} /$

\section{References}

1 For recent reviews on boron cations, see: (a) W. E. Piers, S. C. Bourke and K. D. Conroy, Angew. Chem. Int. Ed. 2005, 44, 5016- 
5036; (b)T. S. De Vries, A. Prokofjevs and E. Vedejs, Chem. Rev. 2012, 112, 4246-4282.

2 For recent examples of borenium cations, see: (a) T. Matsumoto and F. P. Gabbaï, Organometallics, 2009, 28, 4252-4253; (b) D. McArthur, C. P. Butts and D. M. Lindsay, Chem. Commun., 2011, 47, 6650-6652; (c) A. Solovyev, S. J. Geib, E. Lacôte, D. P. Curran, Organometallics, 2012, 31, 54-56; (d) S. Muthaiah, D. C. H. Do, R. Ganguly and D. Vidović, Organometallics, 2013, 32, 6718-6724; (e) Y. Wang, M. Y. Abraham, R. J. Gilliard, D. R. Sexton, P. Wei and G. H. Robinson, Organometallics, 2013, 32, 6639-6642; (f) D. C. H. Do, S. Muthaiah, R. Ganguly and D. Vidović, Organometallics, DOI: 10.1021/om500434r; (g) H. B. Mansaray, A. D. L. Rowe, N. Phillips, J. Niemeyer, M. Kelly, D. A. Addy, J. I. Bates and S. Aldridge, Chem. Commun., 2011, 47, 12295-12297; (h) I. Ghesner, W. E. Piers, M. Parveza and R. McDonald, Chem. Commun., 2005, 2480-2482; (i) C. W. Chiu and F. P. Gabbaï, Organometallics, 2008, 27, 1657-165; (j) E. R. Clark and M. J. Ingleson, Organometallics, 2013, 32, 6712-6717; (k) E. R. Clark, A. Del Grosso and M. J. Ingleson, Chem. Eur. J., 2013, 19, 2462-2466; (1) A. Prokofjevs, J. W. Kampf, A. Solovyev, D. P. Curran and E. Vedejs, J. Am. Chem. Soc., 2013, 135, 15686-15689; (m) M. A. Dureen, A. Lough, T. M. Gilbert and D. W. Stephan, Chem. Commun., 2008, 4303-4305; (n) C. Bonnier, W. E. Piers, M. Parvez and T. S. Sorensen, Chem. Commun., 2008, 4593; (o) D. Vidovic, G. Reeske, M. Findlater and A. H. Cowley, Dalton Trans. 2008, 2293-2297; (p) C. Jones, D. P. Mills, A. Stasch and W. D. Woodul, Main Group Chem., 2010, 9, 23 30 (q) B. Inés, M. Patil, J. Carreras, R. Goddard, W. Thiel and M. Alcarazo, Angew. Chem. Int. Ed., 2011, 50, 8400-8403; (r) C. I. Someya, S. Inoue, C. Präsang, E. Irran and M. Driess, Chem. Commun., 2011, 47, 6599-6601; (s) E. Tsurumaki, S. Hayashi, F. S. Tham, C. A. Reed and A. Osuka, J. Am. Chem. Soc., 2011, 133, 11956-11959.

3 For recent examples of borenium cations in borylation, see: (a) T. S. De Vries, A. Prokofjevs, J. N. Harvey and E. Vedejs, J. Am. Chem. Soc., 2009, 131, 14679-14687; (b) A. Del Grosso, P. J. Singleton, C. A. Muryn and M. J. Ingleson, Angew. Chem., Int. Ed., 2011, 50, 2102-2106; (c) S. A. Solomon, A. Del Grosso, E. R. Clark, V. Bagutski, J. J. W. McDouall, and M. J. Ingleson, Organometallics, 2012, 31, 1908-1916; (d) V. Bagutski, A. Del Grosso, J. A. Carrillo, I. A. Cade, M. D. Helm, J. R. Lawson, P. J. Singleton, S. A. Solomon, T. Marcelli and M. J. Ingleson, J. Am. Chem. Soc., 2013, 135, 474-487; (e) A. Del Grosso, R. G. Pritchard, C. A. Muryn and M. J. Ingleson, Organometallics, 2010, 29, 241-249; (f) A. Del Grosso, M. D. Helm, S. A. Solomon, D. Caras-Quintero and M. J. Ingleson, Chem. Commun., 2011, 47, 12459-12461; (g) M. J. Ingelson, Synlett, 2012, 23, 1411-1415; (h) T. Stahl, K. Müther, Y. Ohki, K. Tatsumi and M. Oestreich, J. Am. Chem. Soc., 2013, 135, 10978-10981.

4 For recent examples of borenium cations in hydroboration, see: (a) A. Prokofjevs, A. Boussonnière, L. Li, H. Bonin, E. Lacôte, D. P. Curran and E. Vedejs, J. Am. Chem. Soc., 2012, 134, 12281-12288; (b) P. Eisenberger, A. M. Bailey and C. M. Crudden, J. Am. Chem. Soc., 2012, 134, 17384-17387; (c) B. Bentivegna, C. I. Mariani, J. R. Smith, S. Ma, A. L. Rheingold, and T. J. Brunker, Organometallics, 2014, 33, 2820-2830.
5 For a recent example of borenium cations in haloboration, see: J. R. Lawson, E. R. Clark, I. A. Cade, S. A. Solomon and M. J. Ingleson, Angew. Chem. Int. Ed., 2013, 52, 7518-7522.

6 For recent examples of borenium cations in hydrosilylation: (a) J. Chen, R. A. Lalancette and F. Jaekle, Chem. Commun., 2013, 49,4893-4895; (b) S. E. Denmark and Y. Ueki, Organometallics, 2013, 32, 6631-6634.

7 For borenium cations in hydrogenation: J. M. Farrell, J. A. Hatnean and D. W. Stephan, J. Am. Chem. Soc., 2012, 134, 15728-15731.

8 For borenium cations in Diels Alder reactions: Q.-Y. Hu, G. Zhou, G and E. J. Corey, J. Am. Chem. Soc. 2004, 126, 13708.

9 For examples of cationic aluminium species, see : (a) L. F. Tietze, A. Schuffenhauer and P. R. Schreiner, J. Am. Chem. Soc. 1998, 120, 7952; (b) Y.-H. Lam, P. H.-Y. Cheong, J. M. Blasco Mata, S. J. Stanway, V. Gouverneur and K. N. Houk, J. Am. Chem. Soc. 2009, 131, 1947-1957.

10 For recent examples of gallium cations, see: (a) S. Tang, J. Monot, A. El-Hellani, B. Michelet, R. Guillot, C. Bour and V. Gandon, Chem. Eur. J., 2012, 18, 10239-10243; (b) A. El-Hellani, J. Monot, R. Guillot, C. Bour and V. Gandon, Inorg. Chem., 2013, 52, 506-514; (c) A. El-Hellani, J. Monot, S. Tang, R. Guillot, C. Bour and V. Gandon, Inorg. Chem., 2013, 52, 11493-11502; (c) C. Bour, J. Monot, S. Tang, R. Guillot, J. Farjon and V. Gandon, Organometallics, 2014, 33, 594-599.

11 For a recent example of an indium cation, see: L.-G. Zhuo, J. J. Zhang and Z.-X. Yu, J. Org. Chem. 2012, 77, 8527-8540.

12 (a) E. Despagnet-Ayoub and R. H. Grubbs, J. Am. Chem. Soc., 2004, 126, 10198-10199; (b) E. Despagnet-Ayoub and R. H. Grubbs, Organometallics 2005, 24, 338-340.

13 H. Nöth and B. Wrackmeyer, in Nuclear Magnetic Resonance Spectroscopy of Boron Compounds, Springer Verlag, Berlin, 1978, Ch. 7, pp. 74-101.

14 S. Alvarez, Dalton Trans., 2013, 42, 8617-8636.

15 S. Ming-Der and S.-Y. Chu, Chem. Phys. Lett., 1999, 308, 283-288.

16 The HOMO is mainly the $\sigma$-lone pair orbital on the central carbon atom while the formally empty p-orbital on the same carbon atom is involved in the formation of the LUMO. For more details see the Supporting Information. 